\title{
Optimization of Total Flavonoids Extraction and A-Glucosidase Inhibitory Activity from Plectranthus amboinicus (Lour.) Spreng. Leaves using the Simplex-Centroid Design
}

\author{
Kunto Wibisono', Syarifah lis Aisyah', Sri Suhesti ${ }^{2}$, Waras Nurcholis ${ }^{3 *}$ \\ 'Department of Agronomy and Horticulture, Faculty of Agronomy, Bogor Agricultural University (IPB \\ University), Bogor, Indonesia. \\ 2Plantation Research and Development Center, Agricultural Research Agency, Ministry of Agriculture, \\ Bogor, Indonesia. \\ ${ }^{3}$ Department of Biochemistry, Faculty of Mathematics and Natural Science, Bogor Agricultural University \\ (IPB University), Bogor, Indonesia. \\ ${ }^{4}$ Tropical Biopharmaca Research Center, Bogor Agricultural University (IPB University), Bogor, Indonesia. \\ *Corresponding author email: wnurcholis@apps.ipb.ac.id
}

Received March 3, 2019; Accepted July 17, 2019; Available online November 30, 2019

\begin{abstract}
The leaves of Plectranthus amboinicus (Lour.) Spreng. (Lamiaceae) is a perennial plant that contained flavonoids compounds with have antidiabetic properties. The aim of the work was to select the best solvent for extraction of the flavonoid compounds from torbangun leaves. A statistical simplex-centroid mixture design for the water, ethanol, and hexane solvents has been used to the extraction of extract yield, flavonoids content, and inhibitory $\alpha$-glucosidase activity of torbangun leaves. The ethanol-water extracts showed the highest extract yield with value of 15.92\%. The ethanol-hexane extracts presented the highest total flavonoids content, $96.30 \mathrm{mg} \mathrm{QE} / \mathrm{g}$, followed by hexane extract (82.91 mg QE/g). The ethanol extract recorded higher inhibitory of $\alpha$-glucosidase activity, with value of $25.53 \%$, followed by hexane extract $(25.21 \%)$, and ethanol-water extract $(23.02 \%)$. The weak correlation between the $\alpha$-glucosidase inhibition and total flavonoids content showed that flavonoids contribute non-significantly to the $\alpha$-glucosidase activity.
\end{abstract}

Keywords: Amboinicus; extraction; flavonoids; glucosidase; Lamiaceae; Plectranthus.

\section{INTRODUCTION}

Plectranthus amboinicus (Lour.) Spreng., family Lamiaceae and commonly known as torbangun name in Indonesia, is a perennial plant that distributed in Asia, Australia, and Tropical Africa (Lukhoba, Simmonds, \& Paton, 2006). In the Bataknese people of Indonesia, torbangun leaves have been traditionally used for lactating women as a breast milk stimulant (Damanik, Wahlqvist, \& Wattanapenpaiboon, 2006). In the herb medicine, the torbangun leaves have been used for antirheumatic (Chang, Cheng, Hung, Chung, \& Wu, 2010), anti-diarrhea (Shubha \& Bhatt, 2015), antibacterial (Aguiar et al., 2015; Vijayakumar, Vinoj, Malaikozhundan, Shanthi, \& Vaseeharan, 2015), anti-fungi (Murthy, Ramalakshmi, \& Srinivas, 2009), anti-streptococcal (Zhang, Wijesundara, Abbey, \& Rupasinghe, 2017), anti-inflammatory and antitumor (Gurgel et al., 2009), and anti-diabetic (Govindaraju \& Arulselvi, 2018) activities.

Polyphenolics, such as flavonoids compounds, are one of the secondary metabolites which contained in the torbangun leaves (El-hawary, El-sofany, AbdelMonem, Ashour, \& Sleem, 2012). They are an interesting material studied due to their several pharmacological activities such as inhibitors of the human UDP-glucuronosyltransferase 1A1 (Liu et al., 2019), inhibitors of $\alpha$-glucosidase (Zhu et al., 2019) and $\alpha$-amylase (Martinez-Gonzalez, Díaz-Sánchez, de la Rosa, Bustos-Jaimes, \& Alvarez-Parrilla, 2019), antioxidant and anti-inflammatory (G.-L. Chen, Fan, Wu, Li, \& Guo, 2019), and antiplasmodial (Tuenter et al., 2019) activities.

The simplex-centroid design has been used as a statistical tool to optimize the flavonoids extraction in the system. This statistical method has been successfully applied to several medicinal plants including Scirpus holoschoenus (Oussaid et al., 2017), Monascus purpureus (Handa, de Lima, Guelfi, Georgetti, \& Ida, 2016), Coffee arabica (Marcheafave et al., 2019), and Tagetes patula (Munhoz et al., 2014). In addition, the solvent type was one of the factors in the extraction technique that successfully applied for laboratory and industry (Cvietko Bubalo, Vidović, Radojčić Redovniković, \& Jokić, 2018; Płotka-Wasylka, Rutkowska, Owczarek, Tobiszewski, \& Namieśnik, 2017). Dirar et al., (2019) reported that the solvents system ethanol-acetone 
were found as the best extraction solvent for the phenolic compound from Flos Sophorae Immaturus. Other study showed which the binary mixtures of water-acetone solvents could be used for obtaining the highest flavonoid extracted from chia seeds (Alcântara et al., 2019).

In recent year, there was no study focus on optimizing the flavonoids extraction from torbangun leaves with using the simplex-centroid design. Therefore, we have tried to optimize the solvent type and their mixtures on the extract yield, flavonoids contents, and activity of a -glucosidase inhibition from torbangun leaves. This study used a simplexcentroid model with water, ethanol, and hexane as solvents to optimize the flavonoids extraction in torbangun leaves. All the extracts were furthermore determined for preliminary evaluation of antidiabetic activity with using mechanism by $\alpha$-glucosidase inhibition.

\section{EXPERIMENTAL SECTION}

\section{Plant material and preparation}

Plectranthus amboinicus (torbangun) leaves were obtained from farmer's garden in Sentul, Bogor, West Java, Indonesia in September 2018. The torbangun sample was confirmed and deposited at Tropical Biopharmaca Research Center, IPB University. Torbangun leaves were cleaned, washed and dried for three days at $50{ }^{\circ} \mathrm{C}$. Dried torbangun, with water content $<10 \%$, was ground using the grinder and passed through a 100-mesh sieve.

\section{Simplex-centroid design for extraction of torbangun leaves}

Extraction solvents system were mixtures of ethanol, water, and hexane, in consist amounts according to the simplex-centroid design in Figure 1. Approximately $15 \mathrm{~g}$ of the dried torbangun leaves powders was extracted with $100 \mathrm{ml}$ of the solvents system in Table 1. The mixtures were placed in the shaker and then macerated in room temperature with shaking at $120 \mathrm{rpm}$ for $24 \mathrm{~h}$. Thereafter, solutions were filtered with Whatman type 4. Finally, the solvent was removed in a rotary evaporator at $50{ }^{\circ} \mathrm{C}$ to obtain the extract. The percentage of extract yield was calculated. The extracts obtained were analyzed separately for total flavonoids content and $\alpha$-glucosidase inhibitory activity.

\section{Analysis of total flavonoids content}

The total flavonoids content was determined using the aluminum trichloride method ([BPOM] Badan Pengawas Obat dan Makanan, 2004). In a 25 mL glass volumetric, the sample or quercetin standard $(10 \mathrm{~mL}$ ) was added with $1 \mathrm{~mL} 10 \%$ aluminum trichloride solution $\left(\mathrm{AlCl}_{3}\right)$ and acetic acid in methanol up to $25 \mathrm{~mL}$. After incubation at room temperature for $30 \mathrm{~min}$, the absorbance sample was measured with a spectrophotometer at wavelength $425 \mathrm{~nm}$. The standard quercetin concentration was $1-20 \mu \mathrm{g} / \mathrm{mL}$, and the absorbance result was used to construct the calibration curve. The total flavonoid content was determined based on the calibration curve of quercetin and expressed as $\mathrm{mg}$ quercetin equivalent per $g$ extract (mg QE/g). All determinations were carried out in three replications.

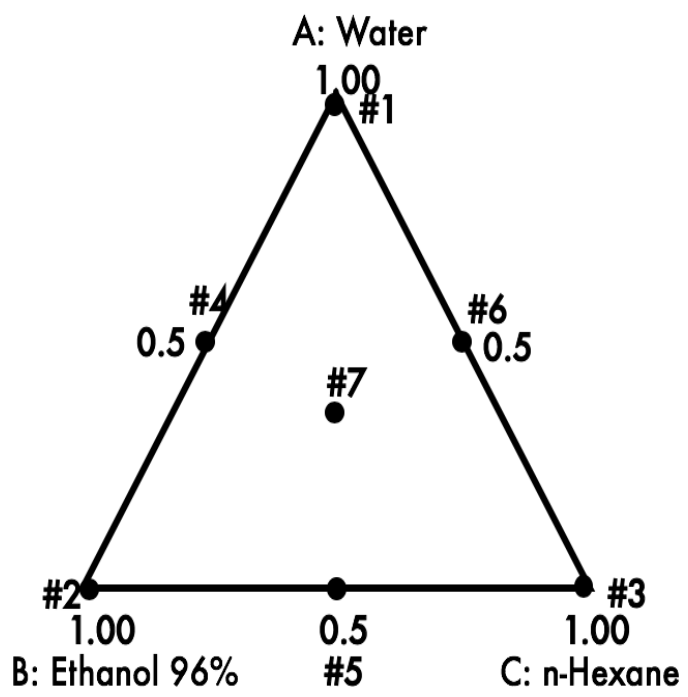

Figure 1. The three axial mixture points of simplexcentroid design used to optimize different solvent on the extraction process.

Table 1. The composition of solvents system among water, ethanol, and hexane in the simplex-centroid design

\begin{tabular}{lccc}
\hline \multirow{3}{*}{ Extract (code) } & \multicolumn{3}{c}{ Solvents mixture } \\
\cline { 2 - 4 } & A & B & C \\
\cline { 2 - 4 } & Water & Ethanol & Hexane \\
\hline Water (w) & 1.0 & 0.0 & 0.0 \\
Ethanol (e) & 0.0 & 1.0 & 0.0 \\
Hexane (h) & 0.0 & 0.0 & 1.0 \\
Water-ethanol (w:e) & 0.5 & 0.5 & 0.0 \\
Ethanol-hexane (e:h) & 0.5 & 0.0 & 0.5 \\
Water-hexane (w:h) & 0.0 & 0.5 & 0.5 \\
Water-ethanol-hexane (w:e:h) & 0.33 & 0.33 & 0.33 \\
\hline
\end{tabular}




\section{Assay for $\alpha$-glucosidase inhibitory activity}

The inhibitor $\alpha$-glucosidase activity of the extracts was evaluated using the method described by (Sancheti, Sancheti, \& Seo, 2009). The analysis was conducted in a 96-well plate. The wells, contained 10 $\mu \mathrm{L}$ of samples $(100 \mu \mathrm{g} / \mathrm{mL})$ were added with $50 \mu \mathrm{L}$ of $0.1 \mathrm{M}$ phosphate buffer $(\mathrm{pH} 7), 25 \mu \mathrm{L}$ of 0.04 $\mathrm{U} / \mathrm{mL} \alpha$-glucosidase, and $25 \mu \mathrm{L}$ of $0.5 \mathrm{mM} \mathrm{p}$ nitrophenyl- $\alpha-D$ glucopyranoside.

The control contained buffer without enzyme. The mixtures were incubated at $37{ }^{\circ} \mathrm{C}$ for $30 \mathrm{~min}$ and stopped using $100 \mu \mathrm{L}$ of $0.2 \mathrm{M} \mathrm{Na}_{2} \mathrm{CO}_{3}$. The absorbance was measured using microplate reader at $410 \mathrm{~nm}$. All analyses were measured in triplicates,

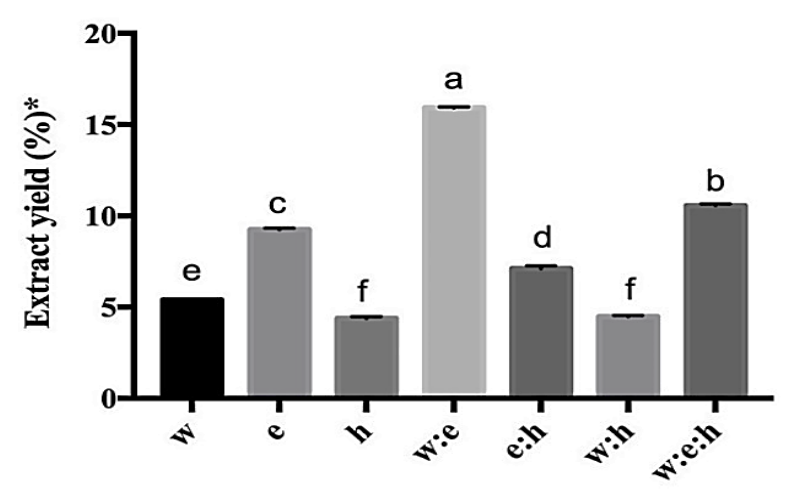

Solvent extractions

Figure 2. The percentage of extract yield in torbangun leaves extracted using the simplexcentroid design. $\mathrm{w}=$ water; $\mathrm{e}=$ ethanol; $\mathrm{h}=$ hexane; $w: e=$ water-ethanol; $e: h=$ ethanolhexane; $\mathrm{w}: \mathrm{h}=$ water-hexane; $\mathrm{w}: \mathrm{e}: \mathrm{h}=$ waterethanol-hexane. *Mean \pm standard deviation of three replicates. Values are marked with different letters indicate statistically significant difference using Duncan test at $\mathrm{P}<0.05$.

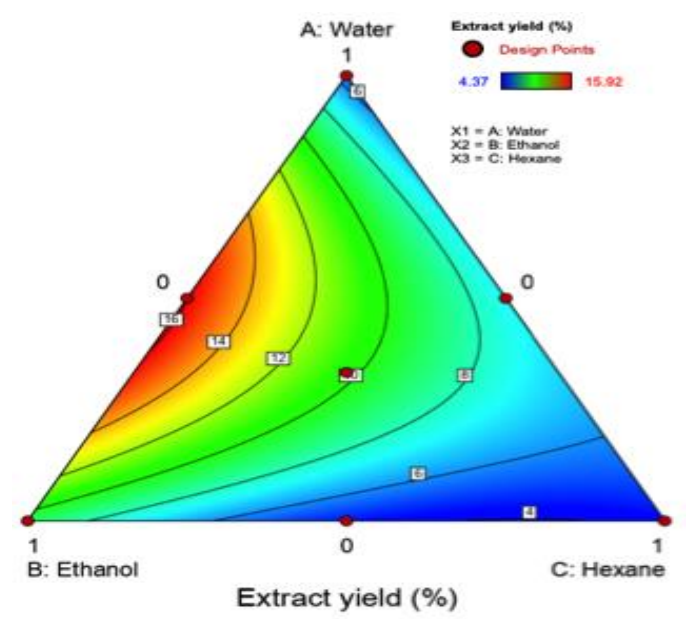

Figure 3. Response curves of the optimized solvents extraction of extract yield in torbangun leaves as a function of the solvents system proportion of water, ethanol, and hexane and inhibitory activity (\%) of the extract was determined using the following formula:

Inhibitory activity $\left.(\%)=\left[\mathrm{A}_{\text {control }}-\mathrm{A}_{\text {sample }}\right) / \mathrm{A}_{\text {control }}\right] \times 100 \%$

\section{Modeling of the experimental data and statistical} analysis

The designing the combination, analyzing the data, fitting the models, and optimizing the solvents proportions was used Design-Expert software version 11. The results were used to compute the predicted equations. ANOVA with Duncan test at $(p<0.05$ ) was performed to evaluate the statistical significance of each response value using SPSS version 25. The heatmap correlation was constructed with MetaboAnalystR 2.0 (Chong, Yamamoto, \& Xia, 2019).

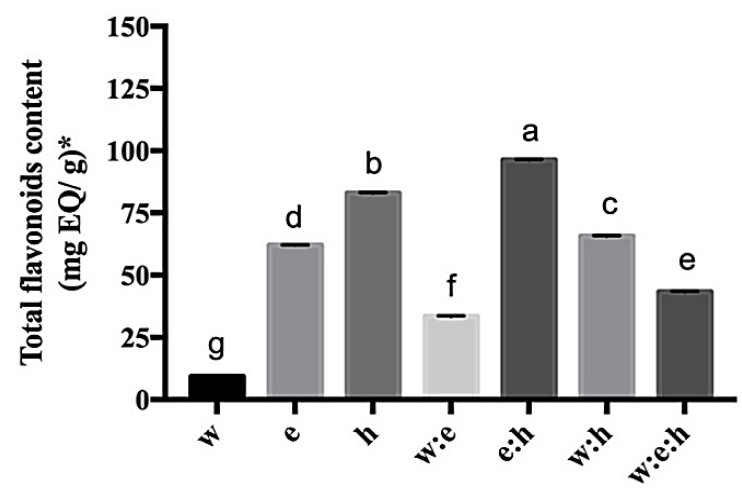

Solvent extractions

Figure 4. Total flavonoid content of different extractsf torbangun leaves. $\mathrm{w}=$ water; $\mathrm{e}=$ ethanol; $\mathrm{h}=$ hexane; $\mathrm{w}: \mathrm{e}=$ water-ethanol; $\mathrm{e}: \mathrm{h}=$ ethanol-hexane; $\mathrm{w}: \mathrm{h}=$ water-hexane; $\mathrm{w}: \mathrm{e}: \mathrm{h}=$ water-ethanol-hexane. *Mean \pm standard deviationof three replicates. Values are marked with different letters indicate statistically significant difference using Duncan test at $P<0.05$.

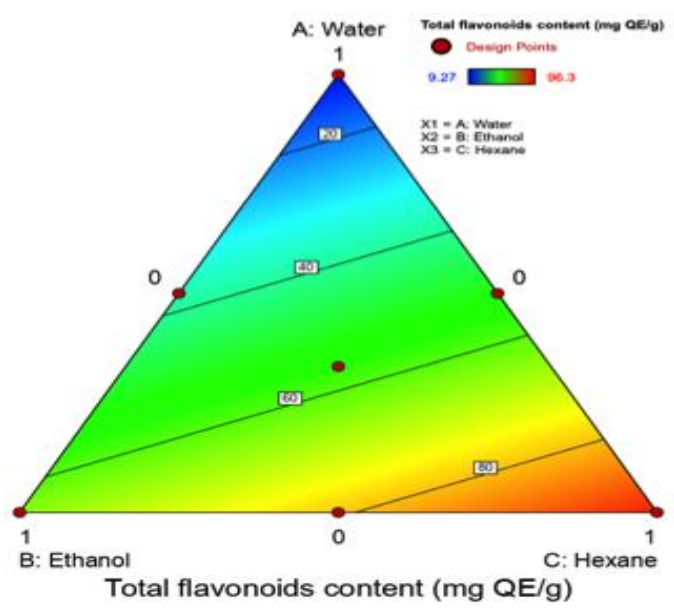

Figure 5. Response curves of the optimized solvents extraction of total flavonoid content in torbangun leaves as a function of the solvents system proportion of water, ethanol, and hexane 


\section{RESULTS AND DISCUSSION}

\section{Optimization of solvents extraction}

Regarding the solvents extraction from torbangun leaves, the solvent system water-ethanol was significant $(p<0.05)$ for the response functions extraction yields (Figure 2).

The best responses (extract yield $=15.92 \%$ ) was estimated when the same solvents system proportions (0.5:0.5, v/v, water-ethanol). Comparing the mean of extract yields demonstrated the following trend: extract yield from pure solvents $(6.33 \%)<$ binary solvent combinations $(9.17 \%)<$ ternary solvent combinations (10.56\%). In pure solvents, hexane gave the lowest extract yield while ethanol gave the maximum yield with water producing middle yields. For the extract yields from binary solvent combinations, higher extract yield was obtained with water-ethanol mixtures and followed by ethanolhexane and water-hexane binary solvents system mixtures. Likewise, Patel, Mahobia, Sheikh, Upwar, \& Singh (2010) reported that the ethanol and water solvent showed extraction best effectively for extract yields in torbangun leaves.

The extract yield was recorded to evaluate the optimize of the extraction solvent used on torbangun leaves. Figure 3 shows the obtained contour plot that gives information about the primary and interaction effects of the solvent proportions for extract yield in torbangun leaves. The quadratic model gave the best fit the response of extract yield with a value of $R^{2}=$ 0.99 . The maximum value on the contour curve demonstrated at positions 4 (water-ethanol, 1:1).

\section{Total flavonoids content}

The ethanol-hexane extract exhibited the highest total flavonoids content $(96.30 \mathrm{mg} \mathrm{QE} / \mathrm{g})$, in which the water extract was the lowest one $(9.27 \mathrm{mg} \mathrm{QE} / \mathrm{g})$ (Figure 4). The total flavonoids content in this study was higher than ethanol extract $(8.85 \mathrm{mg} \mathrm{QE} / \mathrm{g})$,

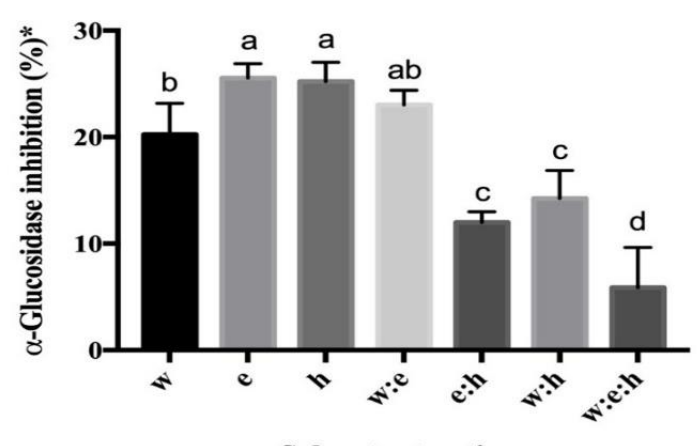

Solvent extractions

Figure 6 . The $\alpha$-glucosidase inhibitory activity of different extracts of torbangun leaves. $\mathrm{w}=$ water; $\mathrm{e}$ $=$ ethanol; $\mathrm{h}=$ hexane; $\mathrm{w}: \mathrm{e}=$ water-ethanol; $\mathrm{e}: \mathrm{h}=$ ethanol-hexane; $\mathrm{w}: \mathrm{h}=$ water-hexane; $\mathrm{w}: \mathrm{e}: \mathrm{h}=$ water-ethanol-hexane. *Mean \pm standard deviation of three replicates. Values are marked with different letters indicate statistically significant difference using Duncan test at $\mathrm{P}<0.05$. acetone extract (6.50 mg QE/g), and butanol extract (2.56 mg QE/g) of India torbangun leaves from previously reported (Sulaiman, Deepak, \& Balachandran, 2018).

The contour curves for total flavonoids content as a function of the proportion composition of ethanol, water and hexane is exhibited in Figure 5. ANOVA was applied to the linear, quadratic, and special cubic models, and the linear model was presented significant lack of fit at the $95 \%$ confidence level for flavonoids content.

The response surface a highest value for flavonoids content of torbangun leaves can be found with an ethanol-hexane $(1: 1)$ binary compositions, while the water solvent was lowest. In pure solvent, the maximum value for flavonoids content was obtained by hexane solvent extraction, followed by ethanol and water solvents. Thus, the hexane and ethanol were the optimize solvent for extracting flavonoids compound from torbangun leaves. Several studies have reported that there are flavonoids types of torbangun leaves which less soluble in water, such as chrysoeriol, cirsimaritin, eriodictol, luteolin, salvigenin, quercetin, 5,41-dihydroxy-6,7-dimethoxy flavone, 5,41-dihydroxy-3,7-dimethoxy flavone, 5-O methyl-luteolin, 3,5,7,31,41-pentahydroxy flavanone, and apigenin (Bhatt, Joseph, Negi, \& Varadaraj, 2013; Y.-S. Chen et al., 2014; El-hawary, El-sofany, Abdel-Monem, \& Ashour, 2012; Ragasa, Pendon, Sangalang, \& Rideout, 1999).

In previous studies have shown that flavonoids torbangun leaves less soluble in water. Several studies has been reported the best solvent extraction for flavonoids compound such as ethanol and acetone (Dirar et al., 2019), water-acetone (Alcântara et al., 2019), acidified solvents of water, acetone, ethanol, and methanol (Arivalagan et al., 2018).

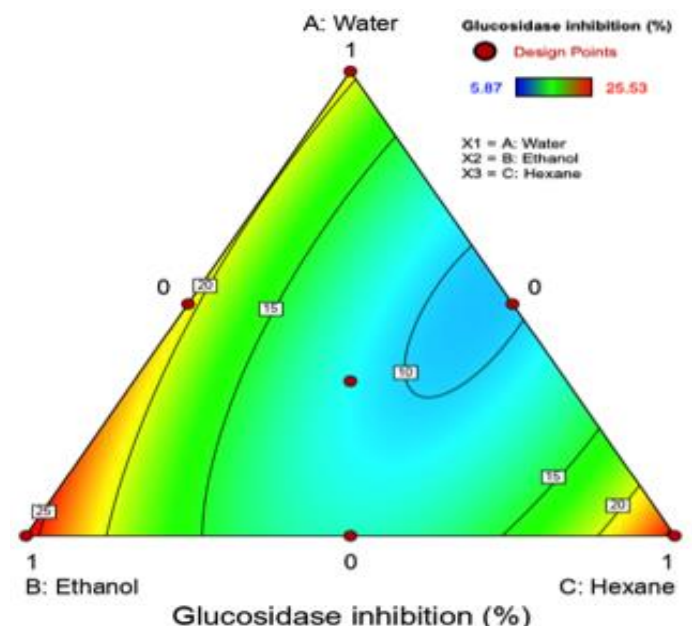

Figure 7. Response curves of the optimized solvents extraction of $\alpha$-glucosidase inhibitory activity in torbangun leaves as a function of the solvents system proportion of water, ethanol, and hexane 


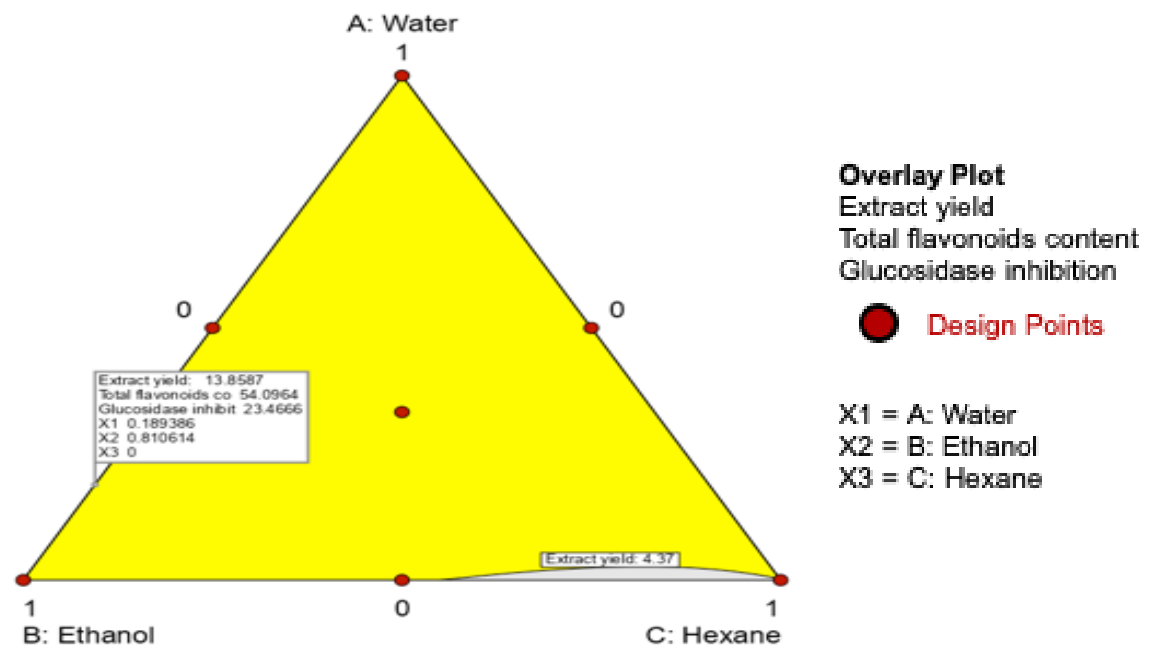

Figure 8. The overlay plot of the responses value for extract yield, total flavonoid content, and $\alpha$ glucosidase inhibition from optimized solvent extraction of torbangun leaves. The graph constructed by constrains criteria in range (0-1) for solvents and maximize for extract yield (4.37 to 15.92), total flavonoids content (9.27 to 96.3), and $\alpha$-glucosidase inhibition (5.87 to 25.53).

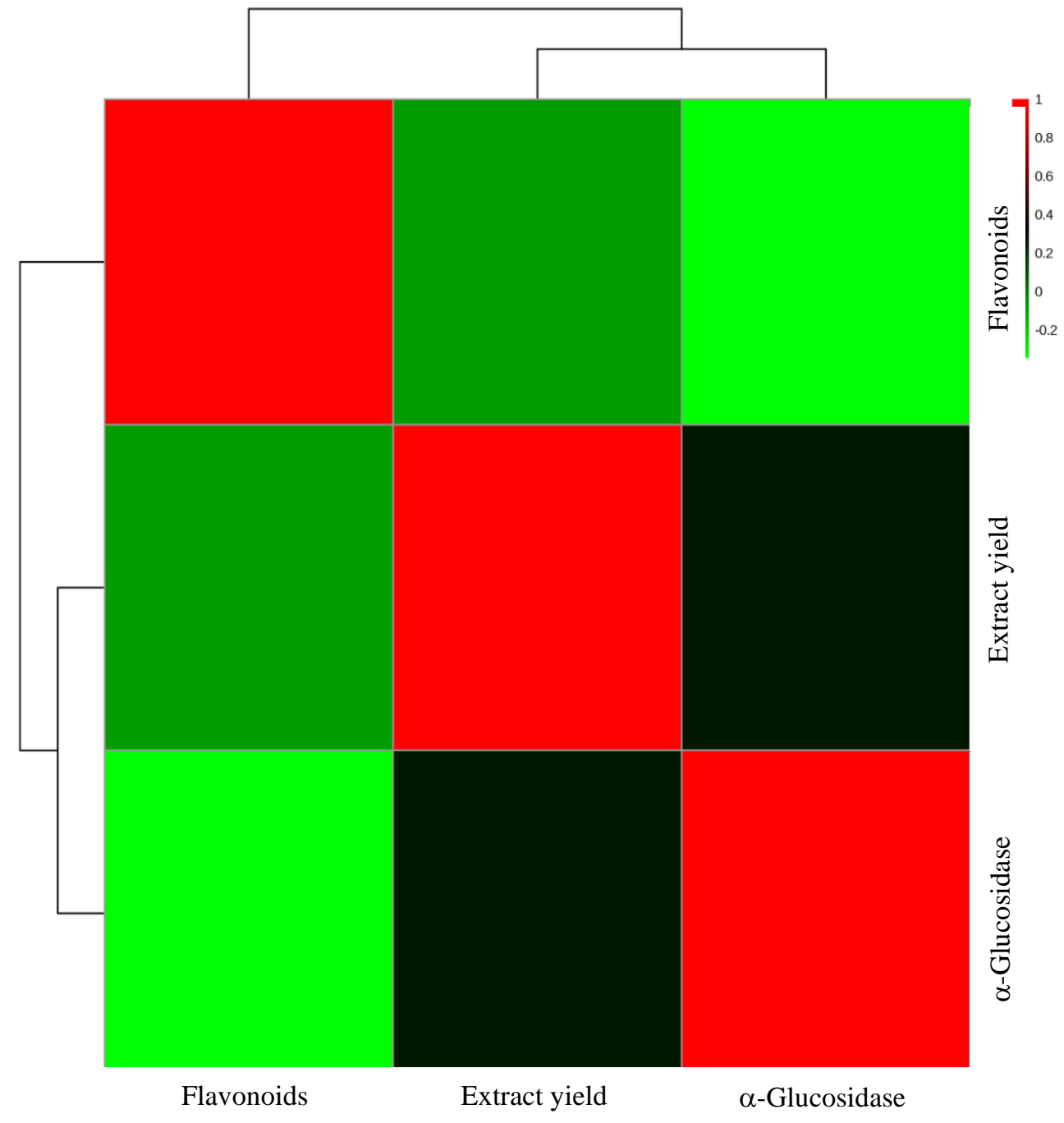

Figure 9. Heatmap showing correlation of the total flavonoids content, extract yield, and $\alpha$-glucosidase inhibitory activity in the torbangun leaves extracts. The color in the heatmap scales ranges from - 1 (green) to 1 (red) that reflected correlation of individual pair of types. 
The response surface for $\alpha$-glucosidase inhibition as a function the percentage mixtures of water, ethanol, and acetone is presented in Figure 7. The result of $\alpha$-glucosidase inhibition can be expressed for model analysis by the quadratic model. In this case water-ethanol, water-hexane, and ethanolhexane are not significant model terms for $\alpha$ glucosidase inhibitory activity response on torbangun leaves extracts. By likening the results, unique can observe that pure ethanol and hexane showed higher inhibitor $\alpha$-glucosidase activity, followed by the pure water and water-ethanol binary solvents system.

\section{Optimization result}

Figure 8 presented the overlay plot and desirability of the extract yield, total flavonoid content, and $\alpha$-glucosidase inhibition in torbangun leaves. The solvent mixtures of water-ethanol (0.19:0.81) were selected as an optimize solvent as significantly fitted suitable with parameters maximum impact of extraction yield, total flavonoids content, and $\alpha$-glucosidase inhibitory activity from torbangun leaves. The desirability of this optimized solvent was 0.72. According to Trini, Rimbawan, Maria, \& Ekowati (2015), the ethanol extract of torbangun leaves exhibit significant potential for antihyperglycemic activity. The ethanol extract from torbangun leaves in this report showed in line than previously reported one. Therefore, a mixture of ethanol and water solvents can be used for obtaining extract rich in flavonoids and with high $\alpha$-glucosidase inhibitory activity from torbangun leaves.

\section{Statistical analysis heatmap correlation}

The several studies were reported a positive correlation between total flavonoid content and $\alpha$ glucosidase inhibition activity (Figueiredo-González et al., 2018; Sheliya et al., 2015). Figure 9 showed no correlation between the $\alpha$-glucosidase inhibition and total flavonoids content in torbangun leaves extract. This result indicated that there is another compound in torbangun leaves that responsible for $\alpha$-glucosidase inhibition. Yuliana, et al., (2018) isolated flavonoid and terpenoid from leaf methanol extract to evaluate of $\alpha$-glucosidase inhibition and found that terpenoid more active than flavonoid. This report is in accordance with the results presented here for hexane extract and ethanol extract.

\section{CONCLUSIONS}

Extraction of flavonoid compounds with $\alpha$ glucosidase inhibitory activity from torbangun leaves was optimized using the simplex centroid design. The flavonoids of torbangun leaves were best extracted with the solvent system ethanol-hexane $(1: 1)$ mixtures. Pure solvent of ethanol and hexane were presented maximum of the $\alpha$-glucosidase inhibitory activity from torbangun leaves.

\section{REFERENCES}

Badan Pengawas Obat dan Makanan. (2004). Monografi Ekstrak Tanaman Obat Indonesia Volume I (Volume I). Jakarta (ID): Direktorat Standardisasi Obat Tradisional, Kosmetik dan Produk Komplemen.

Aguiar, J. J. S., Sousa, C. P. B., Araruna, M. K. A., Silva, M. K. N., Portelo, A. C., Lopes, J. C., ... Matias, E. F. F. (2015). Antibacterial and modifying-antibiotic activities of the essential oils of Ocimum gratissimum L. and Plectranthus amboinicus L. European Journal of Integrative Medicine, 7(2), 151-156. https://doi.org/https://doi.org/10.1016/i.eujim .2014 .10 .005

Alcântara, M. A., de Lima Brito Polari, I., de Albuquerque Meireles, B. R. L., de Lima, A. E. A., da Silva Junior, J. C., de Andrade Vieira, É., ... de Magalhães Cordeiro, A. M. T. (2019). Effect of the solvent composition on the profile of phenolic compounds extracted from chia seeds. Food Chemistry, 275, 489-496. https://doi.org/https://doi.org/10.1016/j.foodc hem.2018.09.133

Arivalagan, M., Roy, T. K., Yasmeen, A. M., Pavithra, K. C., Jwala, P. N., Shivasankara, K. S., ... Kanade, S. R. (2018). Extraction of phenolic compounds with antioxidant potential from coconut (Cocos nucifera L.) testa and identification of phenolic acids and flavonoids using UPLC coupled with TQD-MS/MS. LWT, 92, 116-126. https://doi.org/https://doi.org/ 10.1016/i.Iwt.2018.02.024

Bhatt, P., Joseph, G. S., Negi, P. S., \& Varadaraj, M. C. (2013). Chemical composition and nutraceutical potential of Indian borage (Plectranthus amboinicus) stem extract. Journal of Chemistry, 2013, 1-7.

Chang, J.-M., Cheng, C.-M., Hung, L.-M., Chung, Y.-S., \& Wu, R.-Y. (2010). Potential Use of Plectranthus amboinicus in the Treatment of Rheumatoid Arthritis. Evidence-Based Complementary and Alternative Medicine: ECAM， 7(1), 115-120. https://doi.org/10.1093/ecam/nem 168

Chen, G.-L., Fan, M.-X., Wu, J.-L., Li, N., \& Guo, M.Q. (2019). Antioxidant and anti-inflammatory properties of flavonoids from lotus plumule. Food Chemistry, 277, 706-712. https://doi.org/https://doi.org/10.1016/j.foodc hem.2018.11.040

Chen, Y.-S., Yu, H.-M., Shie, J.-J., Cheng, T.-J. R., Wu, C.-Y., Fang, J.-M., \& Wong, C.-H. (2014). Chemical constituents of Plectranthus amboinicus and the synthetic analogs possessing anti-inflammatory activity. Bioorganic \& Medicinal Chemistry, 22(5), 1766 1772 . https://doi.org/https://doi.org/ 10.1016/i.bmc.2014.01.009 
Chong, J., Yamamoto, M., \& Xia, J. (2019). MetaboAnalystR 2.0: From Raw Spectra to Biological Insights. Metabolites, 9(3), 57. https://doi.org/10.3390/metabo9030057

Cvjetko Bubalo, M., Vidović, S., Radojčić Redovniković, I., \& Jokić, S. (2018). New perspective in extraction of plant biologically active compounds by green solvents. Food and Bioproducts Processing, 109, 52-73. https://doi.org/https://doi.org/10.1016/i.fbp.2 018.03 .001

Damanik, R., Wahlqvist, M. L., \& Wattanapenpaiboon, N. (2006). Lactagogue effects of Torbangun, a Bataknese traditional cuisine. Asia Pacific Journal of Clinical Nutrition, 15(2), 267-274.

Dirar, A. I., Alsaadi, D. H. M., Wada, M., Mohamed, M. A., Watanabe, T., \& Devkota, H. P. (2019). Effects of extraction solvents on total phenolic and flavonoid contents and biological activities of extracts from Sudanese medicinal plants. South African Journal of Botany, 120, 261-267. https://doi.org/https://doi.org/10.1016/i.sajb. 2018.07 .003

El-hawary, S. S., El-sofany, R. H., Abdel-Monem, A. R., \& Ashour, R. S. (2012). Phytochemical Screening, DNA Fingerprinting, and Nutritional Value of Plectranthus amboinicus (Lour.) Spreng. Pharmacognosy Journal, 4(30), 10-13. https://doi.org/https://doi.org/10.5530/pj.201 2.30 .2

El-hawary, S. S., El-sofany, R. H., Abdel-Monem, A. R., Ashour, R. S., \& Sleem, A. A. (2012). Polyphenolics content and biological activity of Plectranthus amboinicus (Lour.) spreng growing in Egypt (Lamiaceae). Pharmacognosy Journal, $4(32)$, 45-54. https://doi.org/https://doi.org/10.5530/pj.201 2.32.9

Figueiredo-González, M., Reboredo-Rodríguez, P., González-Barreiro, C., Carrasco-Pancorbo, A., Cancho-Grande, B., \& Simal-Gándara, J. (2018). The involvement of phenolic-rich extracts from Galician autochthonous extravirgin olive oils against the $\alpha$-glucosidase and $\alpha$-amylase inhibition. Food Research International.

https://doi.org/https://doi.org/10.1016/i.foodr es.2018.08.060

Govindaraju, S., \& Arulselvi, P. I. (2018). Characterization of Coleus aromaticus essential oil and its major constituent carvacrol for in vitro antidiabetic and antiproliferative activities. Journal of Herbs, Spices \& Medicinal Plants, 24(1),

37-51. https://doi.org/10.1080/10496475.2017.136 9483

Gurgel, A. P. A. D., da Silva, J. G., Grangeiro, A. R. S., Oliveira, D. C., Lima, C. M. P., da Silva, A.
C. P., Souza, I. A. (2009). In vivo study of the anti-inflammatory and antitumor activities of leaves from Plectranthus amboinicus (Lour.) Spreng (Lamiaceae). Journal of Ethnopharmacology, 125(2), 361-363. https://doi.org/https://doi.org/10.1016/i.jep.2 009.07.006

Handa, C. L., de Lima, F. S., Guelfi, M. F. G., Georgetti, S. R., \& Ida, E. I. (2016). Multiresponse optimisation of the extraction solvent system for phenolics and antioxidant activities from fermented soy flour using a simplexcentroid design. Food Chemistry, 197, 175184.

https://doi.org/https://doi.org/10.1016/i.foodc hem.2015.10.124

Liu, X.-Y., Lv, X., Wang, P., Ai, C.-Z., Zhou, Q.-H., Finel, M., ... Ge, G.-B. (2019). Inhibition of UGT1A 1 by natural and synthetic flavonoids. International Journal of Biological Macromolecules, 126, 653-661. https://doi.org/https://doi.org/10.1016/i.ijbio mac. 2018.12.171

Lukhoba, C. W., Simmonds, M. S. J., \& Paton, A. J. (2006). Plectranthus: A review of ethnobotanical uses. Journal of Ethnopharmacology, 103(1), 124.

https://doi.org/https://doi.org/10.1016/i.jep.2 005.09 .011

Marcheafave, G. G., Tormena, C. D., Pauli, E. D., Rakocevic, M., Bruns, R. E., \& Scarminio, I. S. (2019). Experimental mixture design solvent effects on pigment extraction and antioxidant activity from Coffea arabica L. leaves. Microchemical Journal, 146, 713-721. https://doi.org/https://doi.org/10.1016/i.micro c. 2019.01 .073

Martinez-Gonzalez, A. I., Díaz-Sánchez, Á. G., de la Rosa, L. A., Bustos-Jaimes, I., \& Alvarez-Parrilla, E. (2019). Inhibition of $\alpha$-amylase by flavonoids: Structure activity relationship (SAR). Spectrochimica Acta Part A: Molecular and Biomolecular Spectroscopy, 206, 437-447. https://doi.org/https://doi.org/10.1016/i.saa.2 018.08 .057

Munhoz, V. M., Longhini, R., Souza, J. R. P., Zequi, J. A. C., Mello, E. V. S. L., Lopes, G. C., \& Mello, J. C. P. (2014). Extraction of flavonoids from Tagetes patula: process optimization and screening for biological activity. Revista Brasileira de Farmacognosia, 24(5), 576-583. https://doi.org/https://doi.org/10.1016/i.bjp.2 014.10 .001

Murthy, P. S., Ramalakshmi, K., \& Srinivas, P. (2009). Fungitoxic activity of Indian borage (Plectranthus amboinicus) volatiles. Food Chemistry, 114(3), 1014-1018. https://doi.org/ https://doi.org/10.1016/j.foodchem.2008.10.0 64 
Oussaid, S., Chibane, M., Madani, K., Amrouche, T., Achat, S., Dahmoune, F., Diaz, M. (2017). Optimization of the extraction of phenolic compounds from Scirpus holoschoenus using a simplex centroid design for antioxidant and antibacterial applications. LWT, 86, 635-642. https://doi.org/https://doi.org/10.1016/i.lwt.2 017.08 .064

Patel, R., Mahobia, N., Sheikh, D., Upwar, N., \& Singh, S. (2010). Phyto-Physicochemical Investigation of Leaves of Plectranthus amboinicus (Lour) Spreng. Pharmacognosy Journal, 2, 536-542. https://doi.org/10.1016/S09753575(10)80057-4

Płołka-Wasylka, J., Rutkowska, M., Owczarek, K., Tobiszewski, M., \& Namieśnik, J. (2017). Extraction with environmentally friendly solvents. TrAC Trends in Analytical Chemistry, 91, 12-25. https://doi.org/https://doi.org/10.1016/i.trac.2 017.03 .006

Ragasa, C. Y., Pendon, Z., Sangalang, V., \& Rideout, J. A. (1999). Antimicrobial flavones from Coleus amboinicus. Philippine Journal of Science, 128(4), 347-352.

Sancheti, S., Sancheti, S., \& Seo, S. Y. (2009). Chaenomeles sinensis: A potent $\alpha$-and $\beta$ glucosidase inhibitor. American Journal of Pharmacology and Toxicology, 4, 8-11. https://doi.org/10.3844/ajptsp.2009.8.11

Sheliya, M. A., Rayhana, B., Ali, A., Pillai, K. K., Aeri, V., Sharma, M., \& Mir, S. R. (2015). Inhibition of $\alpha$-glucosidase by new prenylated flavonoids from euphorbia hirta L. herb. Journal of Ethnopharmacology, 176, 1-8. https://doi.org/https://doi.org/10.1016/i.jep.2 015.10 .018

Shubha, J. R., \& Bhatt, P. (2015). Plectranthus amboinicus leaves stimulate growth of probiotic L. plantarum: Evidence for ethnobotanical use in diarrhea. Journal of Ethnopharmacology, 166, 220-227. https://doi.org/https://doi.org/10.1016/i.jep.2 015.02 .055

Sulaiman, C. T., Deepak, M., \& Balachandran, I. (2018). Spectrophotometric and tandem mass spectroscopic analysis of Indian borage (Plectranthus amboinicus (Lour.) Spreng.) for its polyphenolics characterization. Beni-Suef
University Journal of Basic and Applied Sciences, 7(4), 471-473. https://doi.org/ https://doi.org/10.1016/i.bjbas.2018.04.004

Trini, S., Rimbawan, D. R., Maria, B., \& Ekowati, H. (2015). Antihyperlipidemic Activity of Torbangun Extract (Coleus amboinicus Lour) on Diabetic Rats Induced by Streptozotocin. IOSR Journal of Pharmacy, 2319-4219.

Tuenter, E., Zarev, Y., Matheeussen, A., Elgorashi, E., Pieters, L., \& Foubert, K. (2019). Antiplasmodial prenylated flavonoids from stem bark of Erythrina latissima. Phytochemistry Letters, 30, 169-172. https://doi.org/ https://doi.org/ 10.1016/i.phytol.2019.02.001

Vijayakumar, S., Vinoj, G., Malaikozhundan, B., Shanthi, S., \& Vaseeharan, B. (2015). Plectranthus amboinicus leaf extract mediated synthesis of zinc oxide nanoparticles and its control of methicillin resistant Staphylococcus aureus biofilm and blood sucking mosquito larvae. Spectrochimica Acta Part A: Molecular and Biomolecular Spectroscopy, 137, 886-891. https://doi.org/https://doi.org/10.1016/j.saa.2 014.08 .064

Yuliana, N., Sugiharto, M., Lioe, H., Goto, M., \& Ishikawa, Y. (2018). NMR metabolomics revealed metabolites and bioactivity variation in Torbangun leaves Plectranthus amboinicus L. with different origins. Indonesian Journal of Biotechnology, 23(2), 91-101.

Zhang, B., Wiiesundara, N. M., Abbey, Lord, \& Rupasinghe, H. P. V. (2017). Growing medium amendments effect on growth, secondary metabolites and anti-streptococcal activity of two species of Plectranthus. Journal of Applied Research on Medicinal and Aromatic Plants, 5, 53-59.

https://doi.org/https://doi.org/10.1016/i.jarma p.2016.11.001

Zhu, J., Zhang, B., Wang, B., Li, C., Fu, X., \& Huang, Q. (2019). In-vitro inhibitory effects of flavonoids in Rosa roxburghii and R. sterilis fruits on $\alpha$-glucosidase: Effect of stomach digestion on flavonoids alone and in combination with acarbose. Journal of Functional Foods, 54, 13-21. https://doi.org/https://doi.org/10.1016/i.jff.20 19.01.009 